\title{
Distribution and Abundance of Fish Larvae in South of Alas Strait, West Nusa Tenggara
}

\author{
Irwan Jatmiko*, Fathur Rochman and Gussasta Levi Arnenda \\ Research Institute for Tuna Fisheries \\ Jl. Mertasari 140, Sidakarya, Denpasar, Bali, Indonesia 80223 \\ Email: irwan.jatmiko@gmail.com
}

\begin{abstract}
The early life of fish larvae is important to understand the entire life history of the fish. At this phase, larvae movement is very weak and dependent on the movement of water currents. This study aims to determine the distribution and abundance of fish larvae in the waters south of the Port of Tanjung Luar, West Nusa Tenggara, Indonesia. Sampling of fish larvae were done at five stations at waters around Alas Strait and Indian Ocean south of East Lombok. Sampled were collected from 5 different depth: 0-200 m, 201-1000 m, 1001-2000 m, 2001 $3000 \mathrm{~m}$ and $>3000 \mathrm{~m}$. A total of 122 fish larvae were collected which belong to 26 families and varied compositions among observation stations. The samples was dominated by Scombridae family (18 \%), followed by Carrangidae and Blenniidae (13.1\% and 6.6\%, respectively). The highest abundance was occurred in station $\mathrm{V}(0-$ $200 \mathrm{~m}$ ) of 125 individuals.1000-1 $\mathrm{m}^{3}$. It showed that inshore/shallow waters have more abundance than offshore/deep waters. The findings from this study can be basic information for the authorities to establish sustainable fisheries policy.
\end{abstract}

Keywords: fish, larvae movement, sustainable fishery, early life.

\section{Introduction}

One of the important information to understand the life cycle of fish is to identify the early life of larvae (King, 2010). In this stage, the characterized of the fish organs are not completely formed yet. The movement of the larvae is still very weak so that the level of mobility is very dependent on the movement of water currents. As an energy source at the age of 0-3 days, the larvae are still dependent on yolk that contains of food source. After the yolk finished, the developed larvae feed of phytoplankton and zooplankton. The size of the larvae are very small (microscopic), transparent and body shape is still difficult to distinguish from an adult size (Konishi et al., 2012; Prianto et al., 2013).

One factor determining the conditions of the fish stocks in the waters is the successful recruitment of fish populations. The success of the recruitment process the fish population is strongly influenced by the high success of fish larvae to grow into juveniles and new recruits. The larvae are very susceptible to the high mortality rate and one of them caused by the pressure of predation of predatory organisms (Koster and Mollman, 2000). One strategy in maintaining the survival of larvae, fish eggs and larvae will store in a protected area (Cole, 2008).

The dynamics of fish populations in the early stages of life (early life stages of fishes) greatly affects the adult fish population dynamics. Similarly, the family life, especially fish larvae of Scombridae influences the dynamics and structure of the population of adult fish. Fish larvae population dynamics are affected by migration and the movement of the fish (Amarullah, 2008). During younger age, tuna prefers live in areas of low salinity waters such as shallow waters around the coast. Small tuna fishes (larva and juvenile) movement is more determined by ocean currents (Dahuri, 2008).

According Romimohtarto and Juwana (1998), the presence of fish larvae is influenced by several factors, such as physical environment and the behavior of the parent and the availability of food in the habitat. Availability of food is a major factor in determining the abundance of larvae. This research on larvae is very important to know the beginning of the life cycle of fish species. The study aims to determine the distribution and abundance of fish larvae in the waters south of the Port of Tanjung Luar, West Nusa Tenggara. 


\section{Material and Methods}

Fish larvae were sampled from 5 stations in Alas Strait and the Indian Ocean south of East Lombok, West Nusa Tenggara. Sampling of fish larvae were done using a bongo net with mesh size of $300 \mu \mathrm{m}$ and a mouth diameter of $60 \mathrm{~cm}$ and length of $240 \mathrm{~cm}$, in which at the end of the net is equipped with a sample container of PVC pipe with a diameter of $7 \mathrm{~cm}$ and a length of $38 \mathrm{~cm}$. Bongo net is operated by means of retractable vessel at the stern with anapproximate rate of 1 knot for 10 minutes in the opposite direction flow and at a depth of $10 \mathrm{~m}$ in five (5) different depths station i.e. Station 1 of $0-200 \mathrm{~m}$, station 2 of $201-1000 \mathrm{~m}$, Station 3 of 1001-2000 m, station 4 of 2001-3000 $\mathrm{m}$ and station 5 of more than $3000 \mathrm{~m}$ ) (Figure 1.).

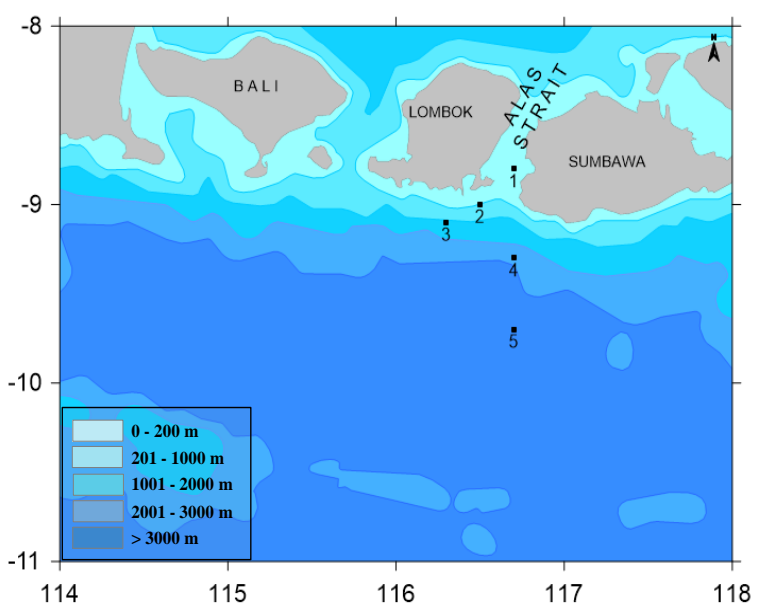

Figure 1. Sampling locations of fish larvae (5 stations) in south of Alas Strait, West Nusa Tenggara.

Samples of fish larvae were put into a bottle and preserved with formalin $10 \%$. The samples were observed in the laboratory of Tuna Fisheries Research Station., Morphological characteristic such as shape of the body, head, eyes, mouth, where the fins chest, abdomen, back, tail fin shape and proportion of the length to the width of the body were observed to distinguish among the family using Nishikawa and Rimmer (1987).

The abundance of fish larvae were calculated using formulaof Junior et al. (2012) as follows:

$$
N=\frac{\sum n}{V f}
$$

$N \quad$ : larvae abundance (ind. $\mathrm{m}^{-3}$ )

$n \quad:$ number of larvae (ind)

Vf $\quad$ : volume of filtered water $(\mathrm{Vflt}=\mid \mathrm{x} \mathrm{t} \times \mathrm{v})$

I $\quad$ : volume of larvae net $\left(\mathrm{m}^{2}\right)$

$t \quad$ : hauled duration (mins)

$v \quad:$ vessel speed (m.mins $\left.{ }^{-1}\right)$

\section{Results and Discussion}

A total of 122 fish larvae belonging to 26 families were identified during this work and had varied compositions among observation stations (Table 1.). The highest number of families (23 families) occurred at the station $\mathrm{V}$ and the lowest ( 3 families) was in station III (Table 2.). Family Scombridae and Carangidae have a wide distributionand can be found throughout the research station, while as many as 24 fish larvae families are found only in certain locations. The highest frequency of occurrence of larval Scombridae in all observation stations (18.0\%) with an average density of 4 larvae found at each station. The frequency of occurrence was low for larvae of Engraulidae, Tripterygidae, Syodontidae, Pomacanthidae and Pomacentridae (0.8\%). See Figure 2.

The number of larval individuals most caught at station I (69 ind.) and the lowest at station III (5 ind.). Station IV and V are in the open zone of the Indian Ocean and faraway from the mainland the influence, while the third and fourth station is located close to the mainland about 5-10 miles and stations are in zone I strait is neritic waters. Station I is the entrance into the waters of East Lombok found most abundance of fish larvae and its type. The composition of the type and the number of individual fish larvae during sampling on all stations always fluctuated. Its might related to the migration of fish looking for appropriate environmental conditions and foods availability. Moreover, this condition might the presence of fish larvae was affected by water currents and tides, which distributes fish larvae to various habitats (Chazarreta et al., 2015).

The abundance of fish larvae in Alas Strait, south of East Lombok for each station was ranged from 8-120 ind.1000-1 $\mathrm{m}^{3}$ and an average of 42.50 ind. $1000^{-1} \mathrm{~m}^{3}$. The highest number was found in the station I and the lowest at station III (Figure 2.). The abundance of larvae in the open ocean water zone (station IV and V) tends to be less than the inshore zone (12 miles). It showed that the abundance of each type of fish larvae at all stations, which is dominated by larval Scombridae with 38.32 ind $1000^{-1} \mathrm{~m}^{3}$ and widely distributed in the middle zone of the open ocean (Station IV) (Figure 3.).

According Romimohtarto and Juwana (1998), the presence of fish larvae is influenced by several factors, physical environment and the behavior of the parent and the availability of food in the habitat. Availability of food is a major factor in determining the abundance of larvae. The larvae are most abundant in the waters in which Chlorophyll-a 
salinity and high Macrozooplankton displacement as food resources (Lang et al., 1994). The difference in abundance of fish larvae at each station is likely caused by physical-chemical factors of different waters. In addition, the condition also affected by the water fertility and geomorphology of sea bed that indirect water fertility will affect phytoplankton become food sources of fish larvae.

Table 1. Frequency and the percentage of fish larvae for each station.

\begin{tabular}{|c|c|c|c|c|c|c|c|c|}
\hline \multirow{2}{*}{ No } & \multirow{2}{*}{ Family } & \multicolumn{5}{|c|}{ Stasiun } & \multirow{2}{*}{ Frequency } & \multirow{2}{*}{ Percentage (\%) } \\
\hline & & 1 & II & III & IV & $\mathrm{V}$ & & \\
\hline 1 & Scombridae & 6 & 1 & 2 & 8 & 5 & 22 & 18.0 \\
\hline 2 & Carangidae & 7 & 6 & 2 & 0 & 1 & 16 & 13.1 \\
\hline 3 & Blenniidae & 5 & 3 & 0 & 0 & 0 & 8 & 6.6 \\
\hline 4 & Leptobramidae & - & 5 & 0 & 1 & 0 & 6 & 4.9 \\
\hline 5 & Pinguipeididae & 5 & 1 & 0 & 0 & 0 & 6 & 4.9 \\
\hline 6 & Lutjanidae & 4 & 0 & 1 & 0 & 0 & 5 & 4.1 \\
\hline 7 & Leiognathidae & 2 & 3 & 0 & 0 & 0 & 5 & 4.1 \\
\hline 8 & Ophiidae & 5 & 0 & 0 & 0 & 0 & 5 & 4.1 \\
\hline 9 & Serranidae & 5 & 0 & 0 & 0 & 0 & 5 & 4.1 \\
\hline 10 & Balistidae & 1 & 1 & 0 & 2 & 0 & 4 & 3.3 \\
\hline 11 & Pomacentridae & 4 & 0 & 0 & 0 & 0 & 4 & 3.3 \\
\hline 12 & Mullidae & 2 & 0 & 0 & 2 & 0 & 4 & 3.3 \\
\hline 13 & Coryphanidae & 1 & 0 & 0 & 0 & 3 & 4 & 3.3 \\
\hline 14 & Chanidae & 4 & 0 & 0 & 0 & 0 & 4 & 3.3 \\
\hline 15 & Clupeidae & 1 & 0 & 0 & 0 & 2 & 3 & 2.5 \\
\hline 16 & Terapontidae & - & 3 & 0 & 0 & 0 & 3 & 2.5 \\
\hline 17 & Fistulariidae & 3 & 0 & 0 & 0 & 0 & 3 & 2.5 \\
\hline 18 & Ambassidae & 3 & 0 & 0 & 0 & 0 & 3 & 2.5 \\
\hline 19 & Gobiidae & 3 & 0 & 0 & 0 & 0 & 3 & 2.5 \\
\hline 20 & Monacanthidae & 2 & 0 & 0 & 0 & 0 & 2 & 1.6 \\
\hline 21 & Deodontidae & 2 & 0 & 0 & 0 & 0 & 2 & 1.6 \\
\hline 22 & Engraulidae & - & 0 & 0 & 0 & 1 & 1 & 0.8 \\
\hline 23 & Tripterygidae & 1 & 0 & 0 & 0 & 0 & 1 & 0.8 \\
\hline 24 & Synodontidae & 1 & 0 & 0 & 0 & 0 & 1 & 0.8 \\
\hline 25 & Pomacanthidae & 1 & 0 & 0 & 0 & 0 & 1 & 0.8 \\
\hline \multirow[t]{2}{*}{26} & Pomacentridae & 1 & 0 & 0 & 0 & 0 & 1 & 0.8 \\
\hline & Total & 69 & 23 & 5 & 13 & 12 & 122 & 100 \\
\hline
\end{tabular}

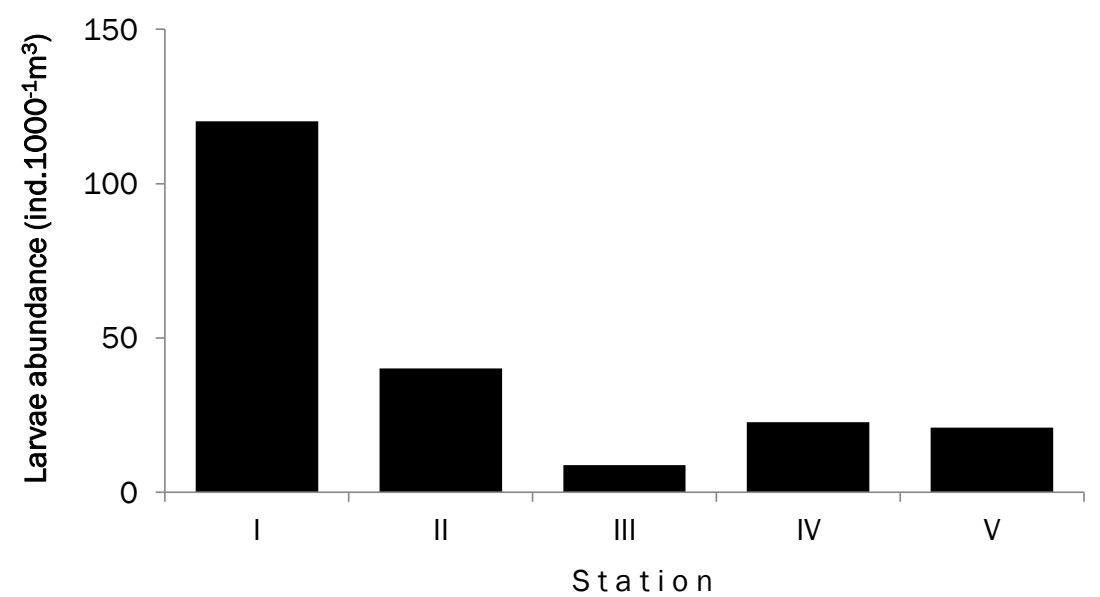

Figure 2. The abundance of fish larvae from five stations of Alas Strait. 
The high abundance of larvae in the station I showed that these location was suitable habitat for spawning and nurturing fish larvae. According to Radtke et al. (2001), in the marine food chain, larvae utilize plankton as their food and the distribution of food and predators will affect the larvae distribution as well.

Based on their life cycle, fish larva was classified into planktonic with passive movement and depending on the conditions of surrounding waters. This is the reason why the abundance of fish larvae in each observation station was significantly difference, depending on the environmental conditions. The larvae of Scombridae and Carangidae families were pelagic and become predominantly found at each sampling station in the Indian Ocean, South of Lombok. Since the sampling locations were in the waters near the mainland (onshore), it can be presumed that these waters are a suitable location for the breeding of fish larvae (nursery grounds). Amarullah (2008) mentions that the fish larvae tend to move towards the coast/onshore transport during the period of water flow moving towards the coast.
The similar result stated by Dahuri (2008) that at younger age, tuna prefers living in relatively low salinity areas such as the shallow waters around the coast. That study also showed that small tuna fishes (larvae and juvenile) movement was more determined by ocean currents.

Scombridae family has wide distribution as found in all observed station, while other 24 families were only found in certain locations (Table 1.). Besides that, fish larvae associated with coral reefs, such as Carangidae and Blennidae family were also found in all observed stations. It was reasonable because the location of the fish larvae at the station relatively close to the beach. The area is very fertile because of the nutrients that flowed from the river from the mainland (Jiang et al., 2015).

The abundance of fish larvae in the open ocean waters zone (station I and II) were less than inshore zone (12 miles). Lucas and Baros (2001) mentioned that the theory of migration hypothesis triangle explicitly separating between spawning ground, nursery grounds and growing ground (adult).

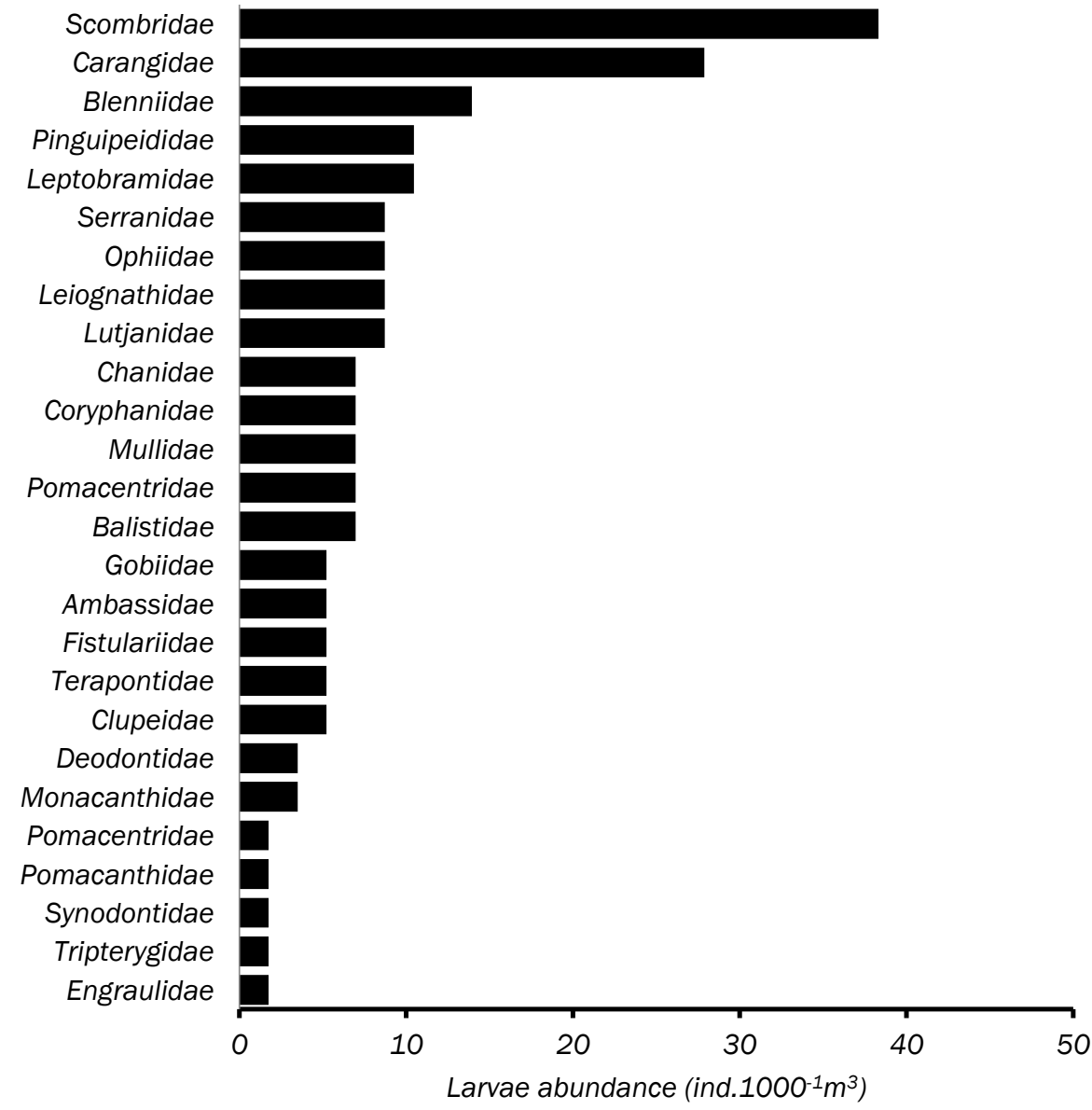

Figure 3. The abundance of fish larvae for each family. 


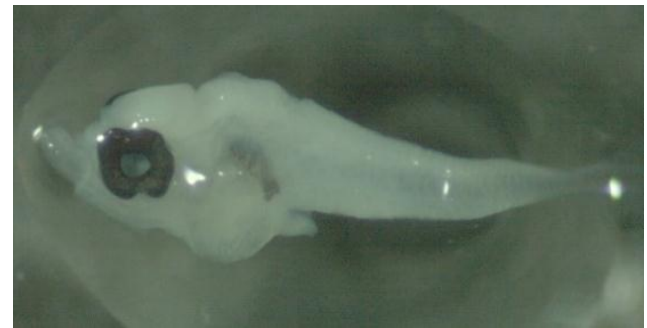

Scombridae

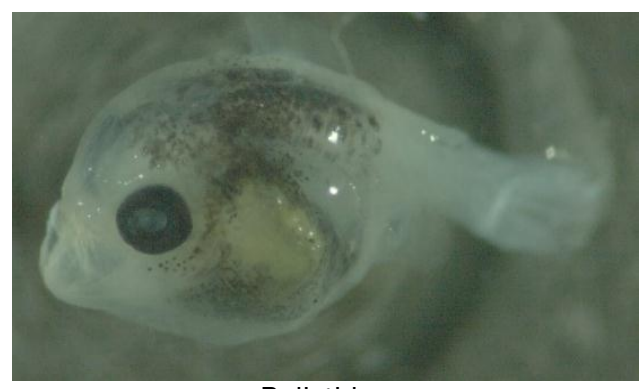

Balistidae

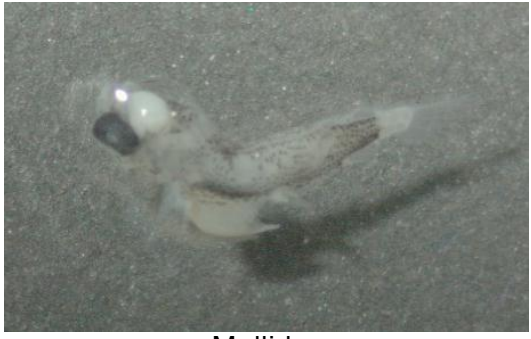

Mullidae

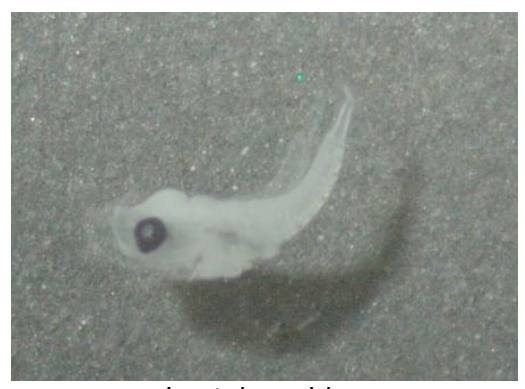

Leptobramidae

Figure 4.Several larvae collected from south of Alas Strait, West Nusa Tenggara

The abundance of fish larvae in the open ocean waters zone (station I and II) were less than inshore zone (12 miles). Lucas and Baros (2001) mentioned that the theory of migration hypothesis triangle explicitly separating between spawning ground, nursery grounds and growing ground (adult). Physical separation of fish life stage is a strategy to obtain favorable environmental conditions for the survival of fish larvae. The dynamics of fish populations in the early stages of life greatly affects the population dynamics of adult fish (Amarullah, 2008). Similarly, the influence of family, especially for Scombridae fish larvae was similar to dynamics and structure of the population of adult fish. Population dynamics influenced by the migration of fish larvae and fish movement (King, 2010).

Differences in abundance of fish larvae at each station were likely caused by physical-chemical factors of the waters. Water current will carry the fish eggs and larvae from spawning, to nursery and then to feeding ground. This occurrence caused the difference of larvae abundance in every different depths. Hereafter, adult fish migration will be influenced by water currents and tides which effect on food availability. This condition can indirectly affect the distribution of fish species geographically (Laevastu and Hela, 1970).

Although located in relatively similar aquatic environments, larvae may exhibit different developments, such as those occurring in Atlantic waters. This suggests the possibility of ecological interactions between larvae in the surface mixed layer (Torres et al., 2011). The interaction among larvae species were commonly occurred for example bluefin tuna larvae in Mediterranean Sea. Mixed larvae, often consist of multiple species, grew together and separate into schools based on size. Strong circulation in this area leads to the formation of a frontal structure resulting from a mass water encounter. Therefore, it can give impact on the fertile waters and abundance of food availability (Aguilar and Lastra, 2009).

Morphology of newly hatched marine fish larvae was generally similar. Eyes is not functioning as well as the mouth and anus. According to Smart et al. (2012) the study of fish eggs and larvae are very effective to determine the relative change in the spawning biomass of fish. Although one spawning fish is able to generate thousands or even millions of eggs, but not all eggs were hatched and developed. Only few dozen grow into adult. Prianto et al. (2013) suggests the presence of larvae in the water is very important, as a successor or substitute the role of adult fish in the future. The disruption to the growth and development of fish larvae will adversely affect fish production as a whole.

\section{Conclusion}

There were 26 fish larvae families found in Alas Strait, West Nusa Tenggara. It is dominated by Scombridae family (18\%) followed by Carrangidae and Blenniidae families (13.1 and 6.6\%, respectively). The highest abundance was found in station V (0-200 m) with around 125 ind.1000-1 $\mathrm{m}^{3}$. It showed that inshore/shallow waters more 
abundance than offshore/deep waters. The results of this study are expected to be basic information to support sustainable fisheries management.

\section{Acknowledgement}

The authors want to thanks to scientific observers from Research Institute for Tuna Fisheries (RITF) for data collection. The authors also thank to fisheries authorities in Tanjung Luar Fishing Port for the assistances during data collection.

\section{References}

Aguilar, R. \& Lastra, P. 2009. Bluefin tuna larval survey: 2008 Oceana-MarViva Mediterranean Project. 76 pp.

Amarullah, M.H. 2008. Hidro-biologi larva ikan dalam proses rekrutmen. J. Hidrosfir Indonesia. 3(2): $75-80$

Chazarreta, J., Hoffmeyer, M.S., Cuadrado, D.G. \& Berasategui, A.A. 2015. Tidal effects on shortterm mesozooplankton distribution in small channels of a temperate-turbid estuary, Southwestern Atlantic. Brazilian J. Oceanograp. 63(2): 83-92. doi: 10.1590/S1679-8759201 5076806302

Cole, K.S. 2008. Observations on spawning behavior and periodicity in the Bluegreen Chromis (Pomacentridae: Chromisviridis). Madang Lagoon, Papua New Guinea. Aqua. Int. J. Ichthyol. 4(1): 27-34.

Dahuri, R. 2008. Restrukturisasi Manajemen Perikanan Tuna. Samudra Komunikasi Utama. Jakarta.

Jiang, M., Li, L., Shen, X.Q. \& Quan, W.M. 2015. Comparison of inshore and offshore fish larval assemblages within the wider Yangtze River estuary (China). J. Appli. Ichthyol. 32(1): 97104. doi: $10.1111 /$ jai.12933

Konishi, Y., Chayakul, R., Chmchan, C. \& Duangdee, T.. 2012. Early Stages of Marine Fishes in Southeast Asian Region. Southeast Asian Fisheries Development Center. Training Department. Thailand. 248 p.

King, M. 2010. Fisheries Biology, Assessment and Management, Second Edition. Oxford, England: Blackwell Publishing Ltd. 381 pp.

Koster, F.W. \& Mollmann, C. 2000. Trophodynamic control by cluepeid predators on recruitment success in Baltic cod. ICESJ. Mar. Sci. 57: 310323.

Laevastu, T. \& Hela, I. 1970. Fisheries Oceanography. Fishering News. London

Lang, K.L., Grimes, C.B., Shaw, R.F. 1994. Variations in the age and growth of yellowfin tuna larvae, Thunnus albacores, collected about the Mississippi River plume. Environ. Biol. Fish. 39(30): 259-270. doi: 10.1007/ BF00005128

Lucas, M.C. \& Baros, E. 2001. Migration of fresh water fishes, Blackwell science. London. 440 pp.

Nishikawa, Y \& Rimmer, D. 1987. Identification of Larval Tunas, Billfishes and other Scombroid Fishes (Suborder Scombroidei): an Illustrated Guide.Commonwealth Scientific and Industrial Research Organization. Marine Research Laboratories. Hobart. Australia.19 p.

Prianto, E., Nurdawaty, S.,\& Kamal, M.M. 2013. Distribusi, Kelimpahan dan Variasi Ukuran Larva Ikan di Estuari Sungai Musi. Bawal. 5(2): 73-79.

Radtke R.L., Kinzie, R. A. \& Shafer, D.J. 2001. Temporal and spatial variation in length of larval life and size at settlement of the Hawaiian amphidromous goby Lentipes concolor. J. Fish Biol. 59(4): 928-938. doi: 10.1111/j.1095-8649.2001.tb00162.x

Romimohtarto, K \&Juwana, S.1998. Plankton larva hewan laut. Pusat Penelitian Oseanografi. Lembaga IImu Pengetahuan Indonesia. Jakarta. $205 \mathrm{pp}$.

Smart, T.I., Duffy-Anderson, J.T., Horne, J.K., Farley, E.V., Wilson, C.D. \& Napp, J.M., 2012. Influence of environment on walleye pollock eggs, larvae, and juveniles in the southeastern Bering Sea. Deep Sea Res. Part II: Topical Studies in Oceanog. 65: 196-207. doi: 10.1016/j.dsr2. 2012.02.018

Torres, A.P., Reglero, P., Balbin, R., Urtizberea, A. \&Alemany, F. 2011. Coexistence of larvae of tuna species and other fish in the surface mixed layer in the NW Mediterranean. J. Plankton Res. 33(12):1793-1812. doi: 10.1093/plankt/fbr078 